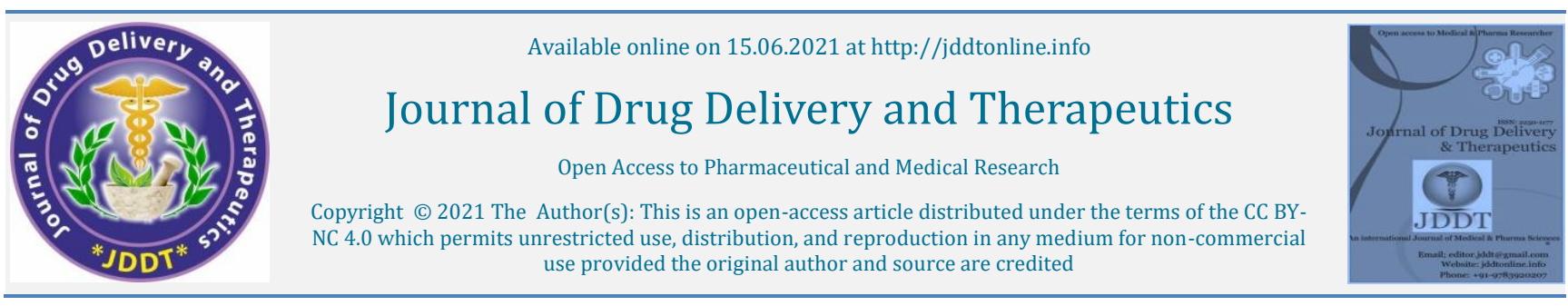

Open Access Full Text Article

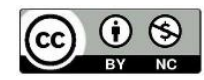

Research Article

\title{
Potential of Allium cepa in thromboembolism in Ulcerative Colitis in Rats
}

\author{
*Ige, Serah Funke and Adekola, Aminat Aderayo \\ Department of Physiology, Faculty of Basic Medical Sciences, College of Health Sciences, Ladoke Akintola University of Technology, P.M.B. 4000, \\ Ogbomoso, Oyo State, Nigeria
}

\section{Article Info:}

$\begin{array}{ll} & \text { Article History: } \\ & \text { Received 19 April 2021 } \\ \text { Review Completed 27 May } 2021 & \text { Accepted 02 June 2021 } \\ \text { Available online 15 June } 2021\end{array}$

Cite this article as:

Ige SF, Adekola AA, Potential of Allium cepa in thromboembolism in Ulcerative Colitis in Rats, Journal of Drug Delivery and Therapeutics. 2021; 11(3-S):74-80

DOI: http://dx.doi.org/10.22270/jddt.v11i3-S.4879

*Address for Correspondence:

Ige, Serah Funke, Department of Physiology, Faculty of Basic Medical Sciences, College of Health Sciences, Ladoke Akintola University of Technology, P.M.B. 4000 , Ogbomoso, Oyo State, Nigeria

\section{Abstract}

Colitis and coagulation influence each other and patients with colitis have been reported to have an increased risk of thromboembolic events. Allium cepa has been reported to have anti-coagulative activity and anti-inflammatory activity. This research was carried out to investigate the effect of Allium cepa on coagulation changes in colitis

Twenty eight rats weighed $180 \pm 20 \mathrm{~g}$ were used for this study. They were divided into four groups; Control group, Colitis group, Allium Cepa + Colitis group and Allium Cepa group. Allium Cepa + Colitis group and Allium Cepa were given $1 \mathrm{ml} / 100 \mathrm{~g}$ body weight of Allium cepa extract daily for 28days orally. Colitis was induced by a single dose of intra-rectal administration of $1 \mathrm{ml} / 100 \mathrm{~g}$ body weight of $6 \%$ acetic acid. Forty eight hours after the colitis induction, blood was taken by cardiac puncture for clotting time test, Prothrombin time (PT), Partial thromboplastin time with kaolin test (PTT.K), platelet count, Calcium ion and Potassium ion test.

Calcium ion was significantly decreased while potassium ion, platelet count, significantly increased and partial thromboplastin time shortened in colitis animals when compared with control. Calcium ion, potassium ion, platelet count and partial thromboplastin time showed no significant difference in Allium Cepa + Colitis group when compared with control. It can be concluded that Allium cepa has potential to reduced the risk of thromboembolism in colitis

Keywords: Colitis, Allium cepa, thromboembolism

\section{INTRODUCTION}

Ulcerative colitis (UC) is a chronic inflammatory condition causing continuous mucosal inflammation of the colon affecting the rectum and a variable extent of the colon in continuity, which is characterized by a relapsing and remitting course. The inflammation in UC is typically confined to the mucosa ${ }^{1,2}$ and the course of the disease is characterized by flares that alternate with periods of remission. It is difficult to predict the flares severity and response to treatment. In addition, prognosis of patients with UC is difficult to determine ${ }^{2}$.

Davie, Ratnoff and Macfarlane have described concept of coagulation along with cascade of proenzyme leading to activation of downstream enzymes ${ }^{3}$. Haemostasis which is also known as coagulation can be defined as arrest of bleeding, comes from Greek, haeme meaning blood and stasis meaning to stop 4 .

Clinical studies and bench research have demonstrated a close link between inflammation and coagulation in inflammatory bowel disease (IBD) ${ }^{5}$. Patients with ulcerative colitis (UC) have an increased risk of thromboembolic events 6 , which appears to be more frequent when IBD is in an active phase $e^{7,8}$ and is affecting the whole colon $8-10$. The incidence of thromboembolic events in patients with IBD has been reported to be 1\%-8\% 11-13. Pulmonary embolism and deep vein thrombosis have been known to be 3 -fold risk increase in inflammatory bowel diseases patient 13-15.

Allium cepa known as onion, has been considered a member of the Liliaceae family for a very long time ${ }^{16,17}$ but according to recent taxonomic schemes the genus Allium belongs to the family Amaryllidaceae, subfamily Allioideae 18 . This genus is one of the largest monocot genera as it contains about 850 species ${ }^{19}$. Allium cepa has been shown to contain 25 active compounds and is packed with similar therapeutic properties 20 . Previous studies have shown that including onion in the diet: stimulate the immune system ${ }^{20}$, reduce symptoms associated with diabetes mellitus, inhibit platelet aggregation, prevent inflammatory processes associated with asthma, was associated with a reduced risk of stomach and brain cancer in humans, inhibited platelet-mediated thrombosis, reduces levels of cholesterol, triglycerides, and thromboxanes, lessen osteoporosis symptoms, inhibit the proliferation of cancer cells 21-23. Allium cepa (Onion), has also been reported to have anti-inflammatory 24 and anticoagulative activity 25-27. Phytochemical studies reveal that Alliums are a rich source of important organic compounds, which are steroid, saponins and flavonoids, and they are characterized by a high content of organo-sulfur compounds that are well absorbed through the gastrointestinal tract, ${ }^{28}$. 
The anti-clotting effect of onions had been ascribed to it content of organo-sulfur compounds 29,30 .

The present study was designed to investigate the possible influence of Allium cepa on coagulation changes in colitis.

\section{MATERIALS AND METHODS}

\section{Experimental Design}

Twenty eight female Wister rats (with weight ranging from 150-200g) were used for this study. The animals were acclimatized for 4 weeks in animal House of the Department of Physiology, Ladoke Akintola University of Technology, Ogbomoso, Oyo State, Nigeria. Animals were allowed with free access to animal feed and water. The animals were grouped into four and treated as follows; Group served as control, colitis group were induced with colitis, Allium cepa + colitis group were treated with Allium cepa for 28days before colitis was induced, Allium cepa group were treated with Allium cepa ( $1.0 \mathrm{ml} / 100 \mathrm{~g}$ body weight) for 28 days.

\section{Colitis Induction}

All animals were weighed and fasted for 24 hours prior to the induction. Colitis was induced by intra-rectal administration of $6 \%$ acetic acid $(1 \mathrm{ml} / 100 \mathrm{~g}$ body weight) after a rectal flushed with $1 \mathrm{ml}$ of distilled water to remove fecal remnant with the aid of rectal cannula in Trendelenburg position and to prevent the acid from coming out, the rats were pressed rectally and held upside down for about 30 seconds.

\section{Preparation of Allium cepa}

Allium cepa was prepared following the previous study procedure with a little modification ${ }^{31}$. 100g of Allium cepa bulbs were peeled and washed thoroughly with distil water and air dried and then blend very well with $15 \mathrm{mls}$ of water daily.

\section{Determination of bleeding time method (BT)}

Bleeding time was done $48 \mathrm{hrs}$ after the animals were induced with colitis before the animals were sacrificed according to reported method [32]. The tail of the rat was warmed for $1 \mathrm{~min}$ in warm water and then dried. Scalpel was used to made a small cut in the middle of the tail, bleeding time started when the first drop touched the circular filter paper and checked at 30 seconds intervals until bleeding stopped.

\section{Animal blood collection}

For the remaining blood coagulation variables, Animal was sacrificed by cervical dislocation, and the blood was drawn by cardiac puncture from the heart with the use of needle and syringe. The blood sample was immediately emptied into sodium citrate bottle for Prothrombin time and Partial thromboplastin time test, lithium heparine bottle for Potassium ion and Calcium ion test, then gently mixed with anticoagulant inside the bottles and centrifuged for $10 \mathrm{~min}$. The remaining blood was divided into plain test tube bottles for clotting time and ethlenediaminetetra-acetic acid (EDTA) bottle for platelet count.

\section{Tissue collection}

After the blood was collected, colon was dissected out and about distal $6 \mathrm{~cm}$ colonic tissues was cut. The colonic was then cut longitudinally and washed in chilled saline solution and weighed with the use of sensitive weighing balance and was visually accessed using macroscopic lens.

\section{Diarrhea scoring method}

The rats were evaluated for diarrhea scoring according to the pattern of Masonobu et al. ${ }^{33}$ as follows: normal feaces-0; loose stool without blood-1; loose stool with visible blood-2; bloody diarrhea-3.

\section{Determination of colon weight and thickness}

The colon was excised and distal $6 \mathrm{~cm}$ of the colon was removed. They were trimmed to remove any adhering tissues. The colon was washed in normal saline to remove fecal remnant and blood. It was then dried and weighed on a sensitive weighing scale to get the colon weight, then the colon thickness was measured.

\section{Macroscopic scoring of colon method}

Macroscopic damage was scored by the scoring system of Wallace and Keenan ${ }^{34}$. The criteria for scoring macroscopic damage were based on a semi quantitative scoring system where features are graded as follows: 0 (no ulcer, no inflammation), 1 (no ulcer, local hyperaemia), 2 (ulceration without hyperaemia), 3 (ulceration and inflammation at one site only), 4 (two or more sites of ulceration and inflammation), 5 (ulceration extending more than $2 \mathrm{~cm}$ ).

\section{Platelet Count}

$20 \mu$ l of whole blood was pipette into $380 \mu$ l of ammonium oxalate. The red cell was allowed to lyse for some minutes. Then the counting chamber was charged with the suspension. It was allowed to settle on the counting chamber. The platelet was counted in 5 boxes at the centre of the chamber. The count was multiply by 1000 .

\section{Procedure for Prothrombin time test}

All reagent and samples were incubated at $37^{\circ} \mathrm{C}$. $50 \mu \mathrm{l}$ of the sample (plasma) was added into pre warmed bottle for 2-5 minutes. $100 \mu \mathrm{l}$ of Prothrombin reagent was added into the sample and the timing was started immediately. The time for clotting was recorded in seconds.

\section{Procedure for partial thromboplastin time test}

All reagent and samples were incubated at $37^{\circ} \mathrm{C} .50 \mu \mathrm{l}$ of the sample (plasma) was added into pre warmed bottle for 2 minutes. $50 \mu$ of PTTK reagent was added and allowed to rest for further 2 minutes. $50 \mu$ l of calcium chloride was then added and the timing was started immediately. It was recorded in seconds.

\section{Procedure For calcium ion test}

$25 \mu \mathrm{l}$ of sample was put into test-tube. $1 \mathrm{ml}$ of worky calcium was added. Then was incubate at room temperature for $10 \mathrm{~min}$. The absorbance was read at $578 \mathrm{~nm}$.

\section{Procedure For potassium ion test}

Ion selective electrode analyser was used to analyse the potassium ion.

\section{Clotting time method}

The coagulation time was determined by placing from 3 to 5 cc. of venous blood in a $15 \mathrm{cc}$. graduated centrifuge tube. The tube was then placed in a water bath at $37^{\circ} \mathrm{C}$, tilting at 30 second intervals until the clot formed.

\section{Statistical Analysis}

Data were expressed as Mean \pm standard error (SEM) of the animal per group. Student T-test analysis was used for statistical analysis comparison and differences were taken as $(\mathrm{P} \leq 0.05)$. 


\section{RESULTS}

Effect of Allium cepa on bleeding time and clotting time in colitis.
There was no significant difference in bleeding time and clotting time across the groups, Table 1.

Table 1: Effect of Allium cepa on bleeding time and clotting time in colitis

\begin{tabular}{|l|l|l|l|l|}
\hline Group & Control & Colitis & Allium cepa + Colitis & Allium cepa \\
\hline Bleeding Time (Seconds) & $71.6 \pm 4.77$ & $89.5 \pm 6.16$ & $83 \pm 8.87$ & $104 \pm 17.75$ \\
\hline Clotting time (Seconds) & $156.8 \pm 12.54$ & $182 \pm 13.0$ & $164.6 \pm 13.18$ & $158 \pm 16.35$ \\
\hline
\end{tabular}

\section{Effect of Allium cepa on plasma calcium ion in colitis.}

There was significant decrease in calcium ion in colitis only group when compared with control. There was no significant difference in calcium ion in Allium cepa + colitis and group Allium cepa groups when compared with control, Figure 1.

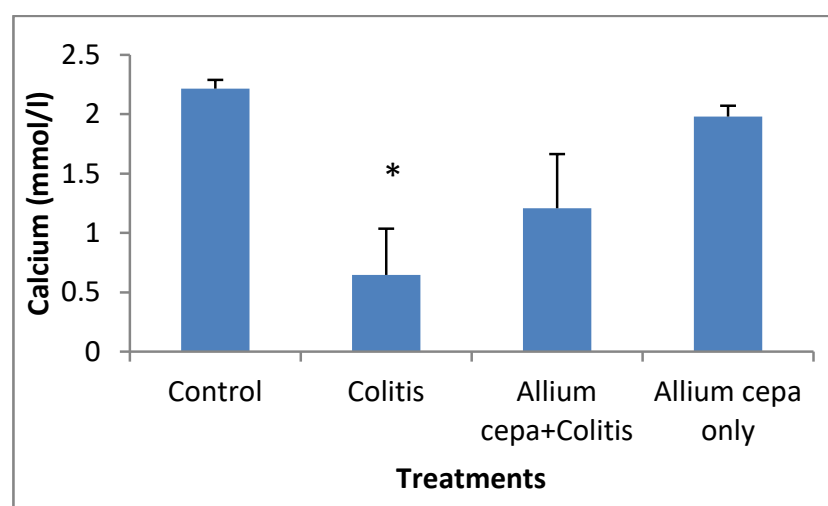

Figure 1: Effect of Allium cepa on calcium ion in colitis.

\section{Effect of Allium cepa on potassium ion in colitis.}

There was significant increase in potassium ion in colitis group when compared with control. There was no significant difference in potassium ion in Allium cepa + colitis and Allium cepa group when compared with control, Figure 2.

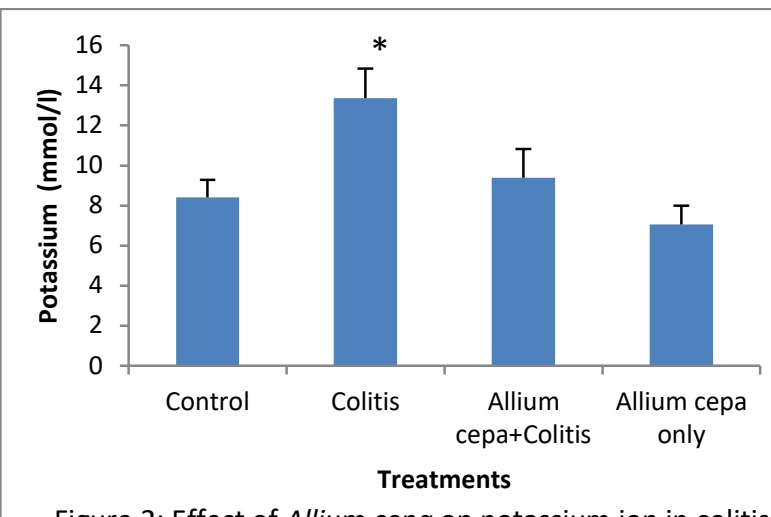

Figure 2: Effect of Allium cepa on potassium ion in colitis.

\section{Effect of Allium cepa on platelet count in colitis.}

There was significant increase in platelet count in colitis group when compared with control. There was no significant difference in platelet count in Allium cepa + colitis and Allium cepa only groups when compared with control, Figure 3.

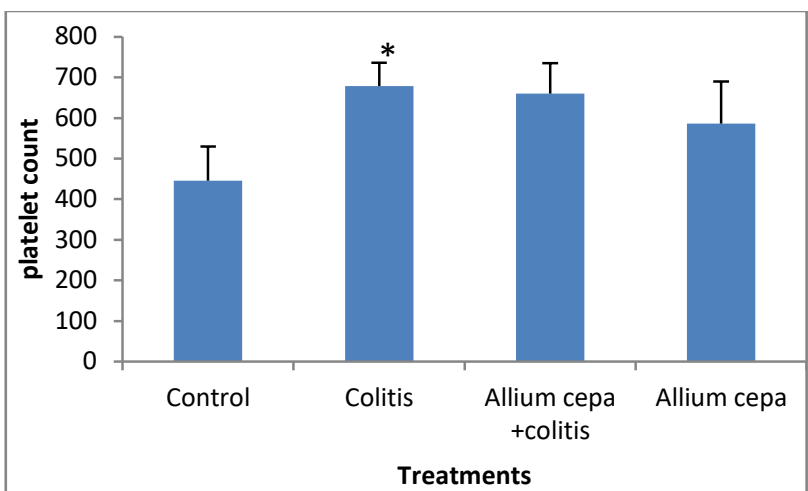

Figure 3: Effect of Allium cepa on platelet count in colitis

\section{Effect of Allium cepa on Prothrombin time in colitis.}

There was no significant difference in Prothrombin time in colitis group, Allium cepa + colitis group, and Allium cepa only group when compared with control. There was significant increase in prothrombin time in Allium cepa + colitis group when compared with colitis group, Figure 4 .

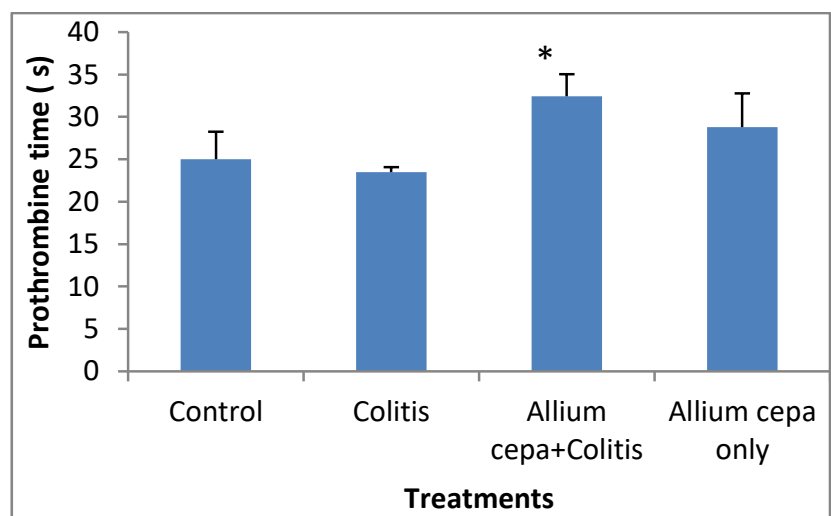

Figure 4: Effect of Allium cepa on prothrombine time in colitis

Effect of Allium cepa on partial thromboplastin time in colitis.

There was significant decrease in partial thromboplastin time in colitis group when compared with control. There was no significant difference in partial thromboplastin time in Allium cepa + colitis and Allium cepa only groups when compared with control. There was significant increase in partial thromboplastin time with kaolin in Allium cepa + colitis and Allium cepa only groups when compared with the colitis group, Figure 5 . 


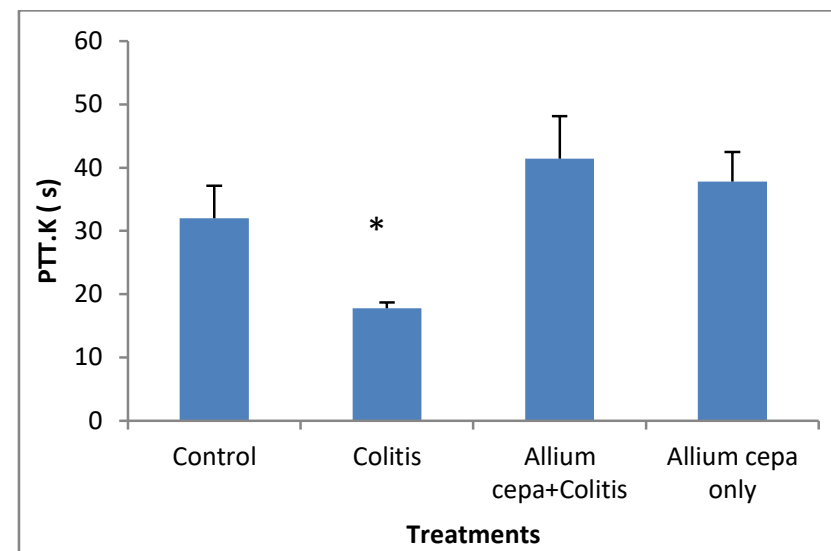

Figure5: Effect of Allium cepa on partial thromboplastin time in colitis

\section{Effect of Allium cepa on colon weight in colitis.}

There was significant increase in colon weight in colitis group and Allium cepa + colitis groups when compared with control. There was no significant difference in colon weight in Allium cepa only group when compared with control, Figure 6.

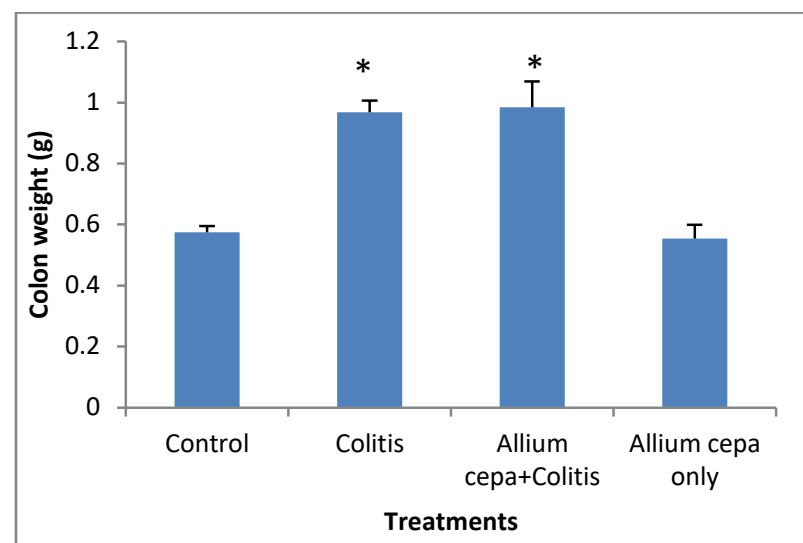

Figure 6: Effect of Allium cepa on colon weight in colitis.

\section{Effect of Allium cepa on macroscopic score in colitis.}

There was significant increase in macroscopic scoring in colitis only group when compared with control. There was no significant difference in macroscopic scoring in Allium cepa + colitis and Allium cepa only group when compared with control, Figure 7.

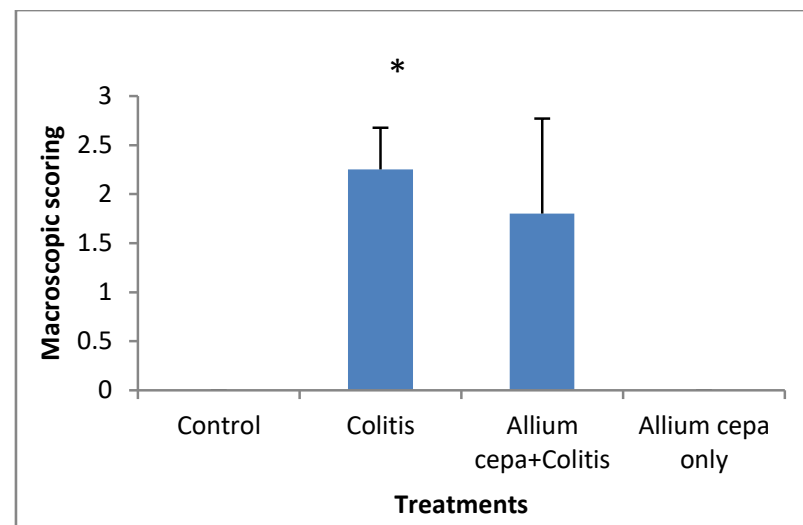

Figure 7: Effect of Allium cepa on macroscopic scoring in colitis.

\section{Effect of Allium cepa on colon thickness in colitis.}

There was significant increase in colon thickness in colitis group when compared with control. There was no significant difference in colon thickness in Allium cepa + colitis and group Allium cepa only groups when compared with control, Figure 8.

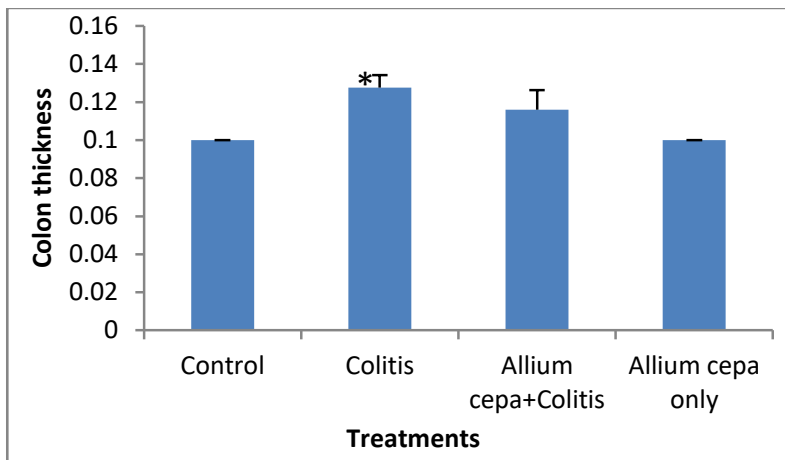

Figure 8: Effect of Allium cepa on colon thickness in colitis.

Effect of Allium cepa on diarrhea scoring after 24 hours of colitis induction in colitis.

There was significant increase in diarrhea score in colitis group when compared with control. There was no significant difference in Allium cepa only and Allium cepa + colitis groups when compared with control, Figure 9.

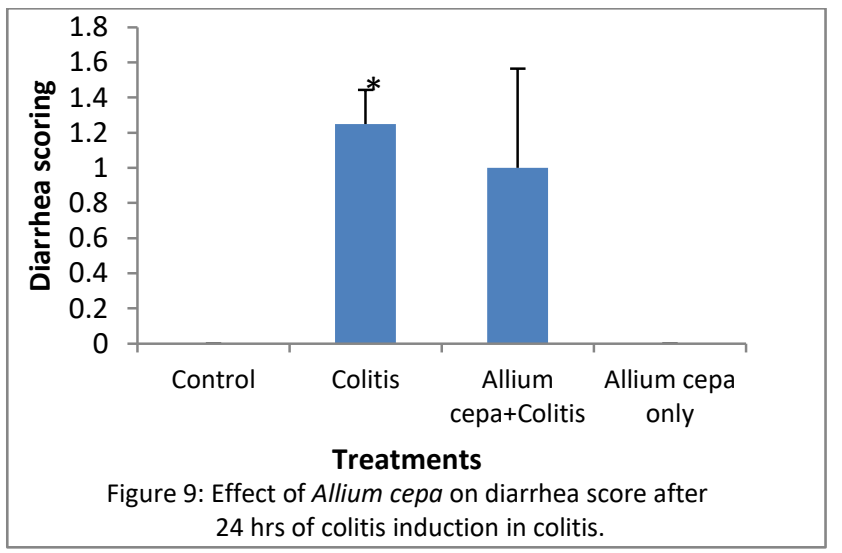

Effect of Allium cepa on diarrhea scoring after 48hours of colitis induction in colitis.

There was non-significant increase in diarrhea score in colitis group when compared with control. There was also no significant difference in diarrhea scoring in Allium cepa + colitis and Allium cepa groups when compared with control, Figure 10.

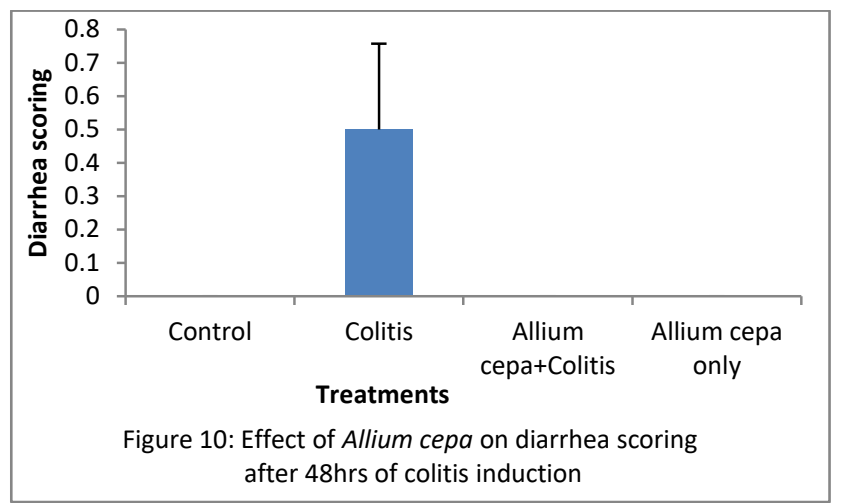




\section{Effect of Allium cepa on change in weight in colitis.}

There was significant decrease in body weight changes of colitis and Allium cepa + colitis groups when compared with control but there was no significance difference in body weight changes Allium cepa group when compared with control. There was no significance difference in Allium cepa + colitis group when compared with colitis group but there was significant increase in Allium cepa only group when compared with colitis group, Figure 11.

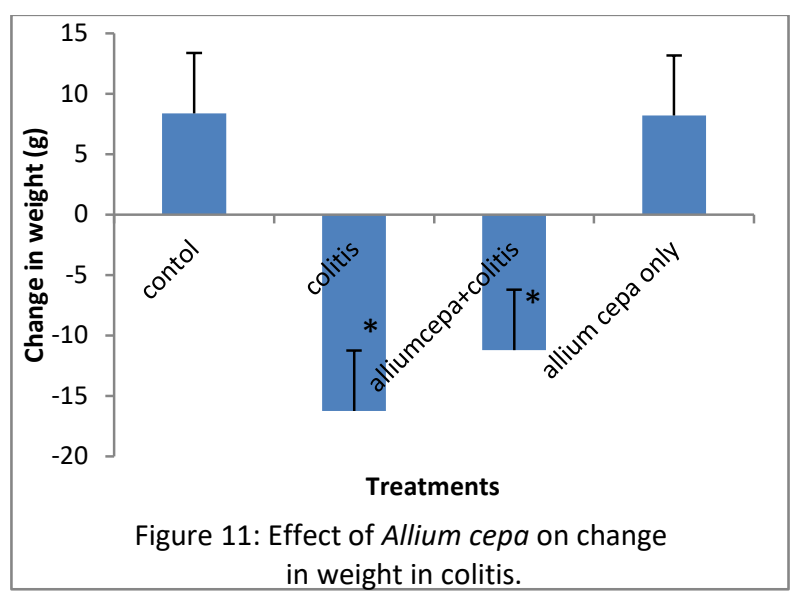

\section{DISCUSSION}

Ulcerative colitis experimentally induced by intra-rectal administration of acetic acid is well recognized model for the study of inflammation bowel disease 35 . The incidence of thromboembolic events in patients with inflammatory bowel disease (IBD) has also been reported to be 1\%-8\% 11-13. Allium cepa have been reported to have anti-inflammatory 24 , and anti-coagulative activity $25,26,36$ which might reduce the incidence of thromboembolic events.

Loss of body weight in colitis observed in this study can be due to deficiency of nutrients resulting from reduced appetite, food aversion or malabsorption, rapid loss of body fluid through colorectal bleeding and diarrhea ${ }^{37}$. This study also revealed that the body weight of the animals with experimental colitis significantly decreased at the end of $48 \mathrm{hrs}$ of colitis induction when compared with control group which can be as result of loss of appetite and diarrhea.

Increased in macroscopic score (extent of tissue damage), colon weight and colon thickness in colitis group can also be due to severe tissue oedema, necrosis and inflammatory cell infiltration 38,39. Macroscopic score and colon thickness showed no significance difference in Allium cepa + colitis group when compared with control which shows that the Allium cepa treatment reduced the inflammation in the treated group.

Diarrhea scoring is useful in checking the stool during the period of colitis. Diarrhea is the hallmark symptom with IBD and is seen in almost $80 \%$ cases ${ }^{40}$. This study revealed significance increase in diarrhea score after $24 \mathrm{hrs}$ of colitis induction in colitis. However, this study also revealed insignificant increase in diarrhea score at the end of 48hours of colitis induction in group colitis group, while there was no significant difference in Allium cepa + colitis group after $24 \mathrm{hrs}$ and $48 \mathrm{hrs}$ when compared with control which might be as a result of Allium cepa treatment given to the group which reduced diarrhea in the group.

This study was carried out to investigate the preventive effect of Allium cepa on coagulation changes in colitis by accessing bleeding time, clotting time, Prothrombin time, partial thromboplastin time, calcium ion and potassium ion on the blood samples.

The screening test in bleeding time and clotting time showed no significant difference in colitis group when compared with control group which is in support of study done by Kazuo et al. ${ }^{41}$ in which they performed studies on blood coagulation in ulcerative colitis and crohn's disease using 14 cases of ulcerative patients, 5 cases of crohn's patients and 3 patients with related disease in which their results showed that bleeding time and clotting time of ulcerative colitis patients were within normal range.

Platelet is involved in the first step of thrombus formation and abnormal platelet function is an established cause of hypercoagualation ${ }^{42}$. The hypercoagulable state in IBD is closely related to abnormal platelet function resulting in a high probability of microvascular thrombosis and microcirculatory dysfunction 43,44. This study revealed significant increased in platelet count in colitis group which is an indication of a definite tendency for platelet increases (thrombocytosis) which support the previous study done by Alkim et al. ${ }^{45}$. However, in this study platelet count of Allium cepa + colitis animals was not significantly different from control which showed that Allium cepa treatment inhibits the increased platelet count.

Prothrombin time (PT) evaluate the extrinsic and common pathway of coagulation which comprise the first step of coagulation. Prothrombin time was found with no significant difference in colitis group when compared with control which against earlier study by Can et al. ${ }^{46}$, while some other studies found no difference in PT between IBD and controls 47,13 which is in agreement with this study and also in support of the study done by Alkim et al. 45 .

Partial thromboplastin time also known as activated partial thromboplastin time (aPTT) evaluate the intrinsic and common pathway of coagulation. Previous studies have found some evidence that short aPTTs are related to a higher incidence of thromboembolic disorders 27,48 and some studies also suggested shorter partial thromboplastin time associated with increased risk of venous thromboembolism 49-51. An association of lower activated partial thromboplastin times with thrombosis could be explained by increased activity of coagulation factors in the intrinsic or common pathways or resistance to activated protein C 48,49,52. Partial thromboplastin time was found with to be significantly shortened in colitis group when compared with control which is in tandem with the study done by Lam et al. 53 , therefore the colitis animals might be at risk of thromboembolism. However, partial thromboplastin time in Allium cepa + colitis animals were not significantly different from the control which showed Allium cepa treatment inhibit shortening of partial thromboplastin time.

Calcium is the most abundant mineral in the human body 54 , with average body stores of $1-2 \mathrm{~kg}, 99 \%$ of which is in skeleton. Intestinal calcium losses are likely aggravated by diarrhea and malabsorption although the extent has not been well studied 55 . Patient with IBD have lower calcium levels in comparison with healthy individuals 56 . This study revealed significant decrease in calcium ion in colitis animals when compared with control which might be due to malabsorption of calcium in the body or calcium loss through diarrhea. Also, calcium ion in Allium cepa + colitis animals were not significantly different from control animals which might be as a result of Allium cepa treatment given to the group which reduce the diarrhea and calcium loss through it. 
Potassium can be released from cellular elements present in blood clotting particularly with severe leucocytosis $(>70,000)$ or thrombocytosis 57 . This study revealed significant increase in potassium ion in colitis animals when compared with control. Also, potassium ion in treated animals with colitis (Allium cepa + colitis) were not significantly different from control which showed the Allium cepa treatment inhibit the increased in potassium ion as a result of colitis inducement.

\section{CONCLUSION}

Based on this study, it can be concluded that Allium cepa can reduced the risk of thromboembolism in colitis animals by inhibiting the increased platelet count and also inhibit shortened of partial thromboplastin time.

\section{Acknowledgments}

Authors acknowledge the technical support of $\mathrm{Mr}$ Ajetunmobi of LAUTECH teaching hospital Ogbomoso, Oyo State, Nigeria.

\section{Conflict of Interest: Nil.}

\section{REFERENCES}

1. Abraham $\mathrm{C}$ and Cho JH, "Inflammatory bowel disease" N. Engl. J. Med., 2009; 361:2066-2078. https://doi.org/10.1056/NEJMra0804647

2. Cosnes J, Gower-Rousseau C, Seksik P and Cortot A, "Epidemiology and natural history of inflammatory bowel diseases." Gastroenterology, 2011; 140:1785-1794. https://doi.org/10.1053/j.gastro.2011.01.055

3. Achneck HE, Sileshi B, Parikh A, Milano CA, Welsby IJ, Lawson JH, "Pathophysiology of bleeding and clotting in the cardiac surgery patient: from vascular endothelium to circulatory assist device surface". Circulation. 2010; 122:2068-77. https://doi.org/10.1161/CIRCULATIONAHA.110.936773

4. Thornton P, Douglas J. "Coagulation in pregnancy." Best Pract Res Clin Obstet Gynaecol., 2010; 24:339-52.

https://doi.org/10.1016/j.bpobgyn.2009.11.010

5. Yoshida H, Granger DN, "Inflammatory bowel disease: a paradigm for the link between coagulation and inflammation." Inflamm Bowel Dis., 2009; 15:1245-1255. https://doi.org/10.1002/ibd.20896

6. Shen J, Ran ZH, Zhang Y, Cai Q, Yin HM, Zhou XT, Xiao SD. "Biomarkers of altered coagulation and fibrinolysis as measures of disease activity in active inflammatory bowel disease: a gender-stratified, cohort analysis." Thromb Res., 2009; 123:604611. https://doi.org/10.1016/j.thromres.2008.04.004

7. Spina L, Saibeni S, Battaglioli T, Peyvandi F, de Franchis R, Vecchi $\mathrm{M}$, "Thrombosis in inflammatory bowel diseases: role of inherited thrombophilia." Am J Gastroenterol; 2005; 100:20362041 https://doi.org/10.1111/j.1572-0241.2005.42029.x

8. Danese S, Papa A, Saibeni S, Repici A, Malesci A, Vecchi M, "Inflammation and coagulation in inflammatory bowel disease: The clot thickens." Am J Gastroenterol, 2007; 102:174-186 https://doi.org/10.1111/j.1572-0241.2006.00943.x

9. Novotny DA, Rubin RJ, Slezak FA, Porter JA, "Arterial thromboembolic complications of inflammatory bowel disease. Report of three cases." Dis Colon Rectum, 1992; 35:193-196 https://doi.org/10.1007/BF02050678

10. Oldenburg B, Van Tuyl BA, van der Griend R, Fijnheer R, van Berge Henegouwen GP, "Risk factors for thromboembolic complications in inflammatory bowel disease: the role of hyperhomocysteinaemia." Dig Dis Sci, 2005; 50:235-240 https://doi.org/10.1007/s10620-005-1588-y

11. Talbot RW, Heppell J, Dozois RR, Beart RW Jr., "Vascular complications of inflammatory bowel disease." Mayo Clin Proc.,
1986; 61:140-145 https://doi.org/10.1016/S00256196(12)65200-8

12. Miehsler W, Reinisch W, Valic E, Osterode W, Tillinger W, Feichtenschlager T, Grisar J, Machold K, Scholz S, Vogelsang H, Novacek G, "Is inflammatory bowel disease an independent and disease specific risk factor for thromboembolism?" Gut , 2004; 53:542-548 https://doi.org/10.1136/gut.2003.025411

13. Kume K, Yamasaki M, Tashiro M, Yoshikawa I, Otsuki M, "Activations of coagulation and fibrinolysis secondary to bowel inflammation in patients with ulcerative colitis." InternMed, 2007; 46:1323-1329

https://doi.org/10.2169/internalmedicine.46.0237

14. Bernstein CN, Blanchard JF, Houston DS, Wajda A, "The incidence of deep venous thrombosis and pulmonary embolism among patients with inflammatory bowel disease: a population-based cohort study." Thromb Haemost , 2001; 85:430-434 https://doi.org/10.1055/s-0037-1615600

15. Bernstein CN, Wajda A, Blanchard JF, "The incidence of arterial thromboembolic diseases in inflammatory bowel disease: a population- based study." Clin Gastroenterol Hepatol, 2008; 6:41-45 https://doi.org/10.1016/j.cgh.2007.09.016

16. Breu W, "Allium cepa L. (onion) Part 1: Chemistry and analysis." Phytomedicine, 1996; 3:293-306. [CrossRef] https://doi.org/10.1016/S0944-7113(96)80069-9

17. Fritsch RM, Friesen N, "Evolution, domestication and taxonomy. In Allium crop science: Recent advances; Rabinowitch, H.D. Currah, L., Eds.; CABI publishing: Stratford-upon-Avon, UK, 2002; pp. 5-30." ISBN 0-85199- 510-1. https://doi.org/10.1079/9780851995106.0005

18. Angiosperm Phylogeny Group,. "An update of the Angiosperm Phylogeny Group classification for the orders and families of flowering plants: APG III." Bot. J. Linn. Soc., 2009; 161:105-121. https://doi.org/10.1111/j.1095-8339.2009.00996.x

19. Peruzzi L, Carta A, "Altinordu, F. Chromosome diversity and evolution in Allium (Allioideae Amaryllidaceae). Plant." Biosyst., 2017; 151:212-220. [CrossRef]

https://doi.org/10.1080/11263504.2016.1149123

20. Chisty M., Quddus R., Islam B and Khan B, "Effect of onion extract on immune response in rabbits." Bangladesh Medical Research Council Bulletin. 1996; 22:81-85.

21. Gazzani G, Papetti A, Daglia M, Berte F, and Gregotti C, "Protective activity of water soluble components of some common diet vegetable on rat liver microsome and the effects of the thermal treatment" Journal of Agriculture and Food Chemistry, 1998; 46:4123-4127. https://doi.org/10.1021/jf980301g

22. Sanderson J, Mclauchlin W, Williamson G, "Quercetin inhibits hydrogen peroxide-induced oxidization of the rat lens." Free Radical in Biology and Medicine, 1999; 26(6):639-645. https://doi.org/10.1016/S0891-5849(98)00262-7

23. Shimura M, ZhouY, Asada Y, Yoshikawa ., Hatake K, Takaku F, Ishizaka Y, "Inhibition of Vpr-induced cell cycle abnormality by quercetin: A novel strategy for searching compounds targeting Vpr." Biochemical and Biophysics Research Communications, 1999; 261:308-316. https://doi.org/10.1006/bbrc.1999.0994

24. Hussein JS, Oraby FS and El-Shafey N, Anti hepatotoxic Effect of Garlic and Onion Oils on Ethanol-induced Liver Injury in Rats. J of Appl Sci Res. 2007; 3(11):1527-153.,

25. Nation S, Yamaguchi N,Yokko Y, "Antioxidative activities of vegetables of the Allium species (studies on natural antioxidants, part II)." Nippon Shokuhin Kogyo Gakkaishi, 1981; 28:230-291.

26. Morimitsu Y, Morioka Y, Kawakishi S, "Inhibitors of platelet aggregation generated from mixture of Allium species and/or Salk(en)yl-Lcysteine sulfoxides." Journal of Agriculture and Food Chemistry, 1992; 40:368- 375. https://doi.org/10.1021/jf00015a002

27. McKenna R, Bachmann F, Miro-Quesada M, "Thromboembolism in patients with abnormally short activated thromboplastin 
time." Thromb Haemost., 1977; 38:893-899.

https://doi.org/10.1055/s-0038-1651907

28. Singh VK, Singh DK, ' Pharmacological Effects of Garlic (Allium sativum L.).' Annu Rev Biomed Sc., 2008; 10:6-26. https://doi.org/10.5016/1806-8774.2008.v10p6

29. Goldman IL, Kopelberg M, Debaene JE "Antiplatelet activity in onion (Allium cepa) is sulfur dependent." Thrombosis and. Haemostasis; 1996; 76:450-452. https://doi.org/10.1055/s0038-1650598

30. Imad M. Taj Eldin, Elhadi M, Ahmed and Abd Elwahab HM "Hypoglycemic Activity and Regeneration of Pancreatic Betacells Produced by Allium cepa in Alloxan-induced Diabetic Rats." Omdurman Journal of Pharmaceutical, 2009; 1(5):562-8

31. Ige SF and Akhigbe RE, Common onion (Allium cepa) extract reverses cadmium-induced organ toxicity and dyslipidaemia via redox alteration in rats. Pathophysiology, 2013; 20:269-274 https://doi.org/10.1016/j.pathophys.2013.04.002

32. Zoja C, Noris M, Corna D, Vigano G, Perico N, de Gaetano G \& Remuzzi G . Lab Invest, 1991; 65:479-483.

33. Masonobu F, Osamu K, Yoshio A, Akira A, Kehchi M, Kohsuke T, Atsushi T, Michio S, Yoshihide F, Masamichi F, Yoshiaki M, Tadao $\mathrm{B}$, "Prebiotic treatment of experimental colitis with germinated barley foodstuff; a comparison with probiotic or antibiotic treatment." Int. J. Mol. Med., 2002; 9:65-70.

34. Wallace JL, Keenan CM, "An orally active inhibitor of leukotriene synthesis accelerates healing in a rat model of colitis." Am I Physiol., 1990; 258:G527-3427. https://doi.org/10.1152/ajpgi.1990.258.4.G527

35. Aleisha AM, Al- Rejajie SS, Ola MS, Ahmed MM, "Pretreatment of gymnema sylvestre revealed the protection against acetic acid induced ulcerative colitis in rats."BMC Complementary and Alternative Medicine, 2014; 14(1) https://doi.org/10.1186/1472-6882-14-49

36. McLellan DS, Jurd K M."Anticoagulants from marine algae." Blood coagulation and fibrinolysis, 1992; 3:69-77. https://doi.org/10.1097/00001721-199202000-00011

37. Owusu G, David D, George K, Newman O, Aaron O, Babatunde M, Duduyemi and Charles A, "Acetic acid induced ulcerative colitis in spraque dawley rats is suppressed by hydroehanolicextract of cordial vignei leaves through reduced serum levels of TNF- $\alpha$ and IL-6." International Journal of Chronic Diseases, . 2020; 87:85497. https://doi.org/10.1155/2020/8785497

38. Harputluoglu MM, Demirel U, Yucel N,. "The effects of Gingko biloba extract on acetic acid-induced colitis in rats."The Turkish Journal of Gastroenterology: the official journal of Turkish Societyl of Gastroenterology, 2006; 17(3):177-182.

39. El-Abhar HS, Hammad A, Gawad A, "Modulating effect of ginger extract on rats with ulcerative colitis" Journal of Ethnopharmacology, 2008; vol. 118, no. 3, pp. 367-372. https://doi.org/10.1016/j.jep.2008.04.026

40. Wenzl HH, "Diarrhea in chronic inflammatory bowel diseases." Gastroenterol Clin North Am., 2012; 41(3):651-75. https://doi.org/10.1016/j.gtc.2012.06.006

41. Kazuo M, Hikaru W, Nobuo H, Kohji S and Yoshio G, "Studies on Blood Coagulation in Ulcerative Colitis and Crohn's Disease." Tohoku J. exp. Med. 1980; 132:93-101 https://doi.org/10.1620/tjem.132.93

42. Dong WG, Liu SP, Zhu HH, Luo HS and Yu JP. "Abnormal function of platelets and role of an $\neg$ gelica sinensis in patients with ulcerative coli $\neg$ tis." World J Gastroenterol, 2004; 10:606-609. https://doi.org/10.3748/wjg.v10.i4.606
43. Van Bodegraven AA, Schoorl M, Baak JP, Linskens RK,Bartels PC, Tunyman HA "Hemostatic imbalance in active and quiescent ulcerative colitis." Am J Gastroenterol., 2001; 96(2):487-493. https://doi.org/10.1111/j.1572-0241.2001.03532.x

44. Larsen TB, Nielsen JN, Fredholm L, "Platelets and anticoagulant capacity in patients with inflammatory bowel disease", Pathophysiol Haemost Thromb., 2002; 32(2):92-96. https://doi.org/10.1159/000065082

45. Alkim H, Ayaz S, Alkim C, Ulker A and Sahin B,. "Continuous Active State of Coagulation System in Patients With Nonthrombotic Inflammatory Bowel Disease." Clin Appl Thromb Hemost; 2011; 17:600-4. https://doi.org/10.1177/1076029611405034

46. Can D, Aliye S, Tulin K, Ali T, Hatice D, Sevim P, Cengiz B, Haci MS, Remzi D, Oya 0, "Coagulation parameters in inflammatory bowel disease." Int J Clin Exp Med, 2014; 7(5):1442-1448.

47. Payzin B, Adakan FY, Yalcin HC, Cetinkaya GS, Berkmen S, Eraslan $\mathrm{S}$ and Unsal B, "Natural co 7 agulation inhibitory proteins and activated pro $\neg$ tein $\mathrm{C}$ resistance in Turkish patients with in $\neg$ flammatory bowel disease." Turk J Gastroenterol, 2006; 17:183-190.

48. Landi G, D'Angelo A, Boccardi E, et al "Venous thromboembolism in acute stroke: prognostic importance of hypercoagulability." Arch Neurol.,1992; 49:279-283 https://doi.org/10.1001/archneur.1992.00530270093024

49. Aboud MR, Ma DD. 'Increased incidence of venous thrombosis in patients with shortened activated partial thromboplastin times and low ratios for activated protein $C$ resistance' Clinical \& Laboratory Haematology, 2001; 23(6):411-6. [PubMed: 11843891] https://doi.org/10.1046/j.1365-2257.2001.00421.x

50. Tripodi A, Chantarangkul V, Martinelli I, Bucciarelli P, Mannucci PM, "A shortened activated partial thromboplastin time is associated with the risk of venous thromboembolism." Blood., 2004; 104(12):3631-4. [PubMed: 15297315]. https://doi.org/10.1182/blood-2004-03-1042

51. Hron G, Eichinger S, Weltermann A, Quehenberger P, Halbmayer WM, Kyrle PA, "Prediction of recurrent venous thromboembolism by the activated partial thromboplastin time." J Thromb Haemost; 2006 4(4):752- 6. [PubMed: 16634742] https://doi.org/10.1111/j.1538-7836.2006.01868.x

52. Svensson PJ, Dahlback B, "Resistance to activated protein C as a basis for venous thrombosis." N Engl J Med., 1994; 330(8):517522. [PubMed: 8302317] https://doi.org/10.1056/NEJM199402243300801

53. Lam A, Borda IT, Inwood MJ and Thomson S, "Coagulation studies in ulcerative colitis and Crohn's disease." Gastroenterology; 1975; 68: 245251. https://doi.org/10.1016/S0016-5085(75)80005-9

54. Caroline H, Viveca R, Uma M, "Micronutrient deficiencies in inflammatory bowel disease." Inflamm Bowel Dis; 2012; 18:1961-1981. https://doi.org/10.1002/ibd.22906

55. Bronner F, "Mechanism of intestinal absorption." Chem. ; 2003; 88:387- 393. https://doi.org/10.1002/jcb.10330

56. Krela-Kazmierczak I, Szymczak A, Lykowsks-Szuber L, Elder P, Horst- SikorskaW, "The importance of vitamin D in the pathology of bone metabolism in inflammatory bowel disease." Arch Med Sci. AMS, 2015; 11:1028-1032.

57. Weiner ID, Linas S, "Disorder of potassium metabolism, comprehensive clinical nephrology 6th ed." Elseivier, 2019; pp. 111-123 